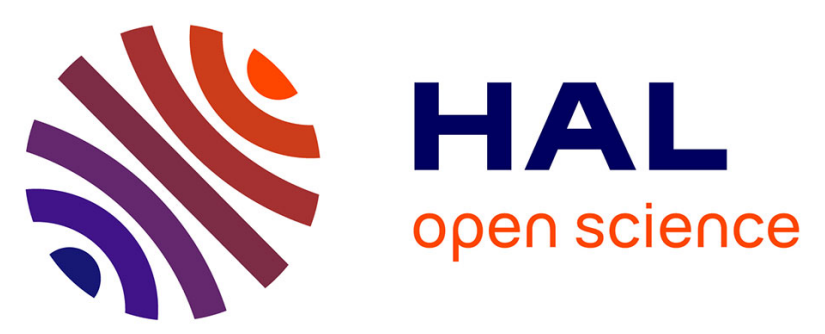

\title{
Alongshore-Variable Beach and Dune Changes on the Timescales from Days (Storms) to Decades Along the Rip-dominated Beaches of the Gironde Coast, SW France
}

Bruno Castelle, Vincent Marieu, Stéphane Bujan

\section{To cite this version:}

Bruno Castelle, Vincent Marieu, Stéphane Bujan. Alongshore-Variable Beach and Dune Changes on the Timescales from Days (Storms) to Decades Along the Rip-dominated Beaches of the Gironde Coast, SW France. Journal of Coastal Research, 2019, 88 (sp1), pp.157 - 171. 10.2112/SI88-012.1 . hal-02385617

\section{HAL Id: hal-02385617 \\ https://hal.science/hal-02385617}

Submitted on 5 Dec 2019

HAL is a multi-disciplinary open access archive for the deposit and dissemination of scientific research documents, whether they are published or not. The documents may come from teaching and research institutions in France or abroad, or from public or private research centers.
L'archive ouverte pluridisciplinaire HAL, est destinée au dépôt et à la diffusion de documents scientifiques de niveau recherche, publiés ou non, émanant des établissements d'enseignement et de recherche français ou étrangers, des laboratoires publics ou privés. 


\title{
Alongshore-Variable Beach and Dune Changes on the Timescales from Days (Storms) to Decades Along the Rip-dominated Beaches of the Gironde Coast, SW France
}

\author{
Bruno Castelle $\dagger^{\dagger *}$, Vincent Marieu ${ }^{\dagger}$, and Stéphane Bujan \\ †UMR EPOC \\ CNRS / Univ. Bordeaux \\ Pessac, France
}

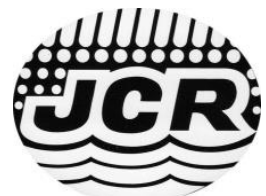

www.JCRonline.org

\begin{abstract}
Castelle, B.; Marieu, V., and Bujan S., 2019. Alongshore-variable beach and dune changes on the timescales from days (storms) to decades along the rip-dominated beaches of the Gironde Coast, SW France. In: Castelle, B. and Chaumillon, E. (eds.), Coastal Evolution under Climate Change along the Tropical Overseas and Temperate Metropolitan France. Journal of Coastal Research, Special Issue No. 88, pp. 157-171. Coconut Creek (Florida), ISSN 0749-0208.

The high-energy meso-macrotidal 110-km long Gironde coast, SW France, is primary composed of quasi-straight sandy beaches bordered by high and wide coastal dunes. Beaches are intermediate double-barred and are essentially morphologically variable alongshore with ubiquitous rip channels incising both bars. These rip channels enforce a strong alongshore variability in the morphology of the dry beach and/or of the dune, morphological patterns referred to as megacusp embayments. In this study, we use 70-year diachronic shoreline data, 3.5-year semi-annual in situ shoreline surveys since 2014, combined with 12.5 -year monthly to semi-monthly topographic surveys collected since 2005 at Truc Vert beach. Results show that 2 types of megacusp can be identified: (1) accretive megacusps on the upper beach, forming through a sequence of accretionary beach states following a storm event, are enforced by innerbar rip channels with a spacing of $\mathrm{O}(100 \mathrm{~m})$ and a typical lifetime of a few months and (2) erosive megacusps cutting the dune, forming during severe-storm driven erosive events, which are primarily enforced by the outer-bar morphology with a spacing of $\mathrm{O}(1000 \mathrm{~m})$. These erosive megacusps do not migrate alongshore and can persist for years to decades. The outstanding winter of 2013/2014 drove the formation of erosive megacusps all along the coast, dramatically altered the coastal landscape and also impacted the behaviour and mean spacing of the accretive megacusps during the subsequent years. Overall, the study demonstrates the complex interplay between the nearshore morphology and the alongshore-variable changes of the foreshore/backshore from the timescales of days to decades, with accessional outstanding winters having the potential to deeply affect beach morphology and rhythmicity on the time scale of a few years, at least.
\end{abstract}

ADDITIONAL INDEX WORDS: Coastal monitoring; sandy coast; beach-dune system; megacusps; rip channels.

\section{INTRODUCTION}

Sandy beaches are highly variable alongshore (e.g., Blossier $e t$ $a l ., 2017)$ owing to the presence of a wide range of bedforms such as, for instance, ripples and megaripples $(\mathrm{O}(0.1-1 \mathrm{~m})$, e.g., Gallagher, Elgar, and Thornton, 1998), beach cusps (O(1-10 m), e.g., Guza and Inman, 1975), rip-channelled surfzone sandbars $(\mathrm{O}(10-1000 \mathrm{~m})$, e.g., Van Enckevort et al., 2004), sorted bedforms in the inner shelf $(\mathrm{O}(100-1000 \mathrm{~m})$, Murray and Thieler, 2004) and shoreline rhythms (O(100-100000 m), Ashton, Murray, and Arnault (2001). Although infragravity edge waves (Hesp, 1993) have long been hypothesised to be the primary driver of alongshore-variable surfzone patterns in the sand, it is now well established that these bedforms are morphodynamic instabilities primarily arising from the positive feedback between different hydrodynamics and sediment transport processes (Coco and Murray, 2007). For instance, shoreline instabilities form through the positive feedback between the longshore drift under

DOI: 10.2112/SI88-012.1 received 27 April 2018; accepted in revision 5 April 2019.

*Corresponding author: Bruno.castelle@u-bordeaux.fr

${ }^{\circ}$ Coastal Education and Research Foundation, Inc. 2019 highly obliquely incident waves and shoreline evolution (Ashton and Murray, 2006), while sorted bedforms in the inner shelf form through a positive feedback mechanism primarily driven by variations in sediment composition with the topographic changes being secondary (Murray and Thieler, 2004). In addition, the different bedforms can sometimes be coupled morphologically (e.g., Castelle et al., 2010a; Coco et al., 2005; Holland and Holman, 1996; Price and Ruessink, 2013; Price et al., 2013; Price, Ruessink, and Castelle, 2014; Sonu, 1973), with morphological coupling and self-organisation mechanisms sometimes coexisting, blurring the interactions between the different bedforms and affecting their morphology and alongshore rhythmicity (Castelle et al., 2010b).

Rip-channelled surfzone sandbars are nearshore morphodynamic instabilities developing as a result of the positive feedback between waves, breaking wave-induced rip-flow circulation (Castelle et al., 2016; Dalrymple, MacMahan, and Reniers, 2011; MacMahan, Thornton, and Reniers, 2006), sediment transport, and the evolving bathymetry (Falqués, Coco, and Huntley, 2000). Rip channels are often part of an accretionary down-state sequence developing from an alongshore-uniform barred-beach state following a storm event (see Dubarbier et al., 
2017 and Wright and Short, 1984 for numerical and field evidence, respectively). During this extended period of beach recovery, shoals develop from the shallowest sections of the alongshore bar that progressively migrate onshore, and in some cases can even attach to the beach (Van Enckevort et al., 2004). During this sequence rip currents flow offshore through the deeper channels (Figure 1a), transport sediment seaward (Aagaard, Greenwood, and Nielsen, 1997) and enforce some morphological variability of the upper part of the beach referred to as megacusps. Megacusp embayments (Figure 1) can be considered as the erosive signature at the shoreline of the presence of rip currents (also known as rip current embayment, Shepard et al., 1941) that transport sediment seaward.

Megacusp embayments have been rarely observed facing the shallower shoals of the sandbar (Balouin, Tesson, and Gervais, 2013; Birrien et al., 2013; Orzech et al., 2011), as they typically face the deeper sandbar channels (e.g., Aagaard, 1998; Birrien et al., 2013; Enjalbert et al., 2011; Ranasinghe et al., 2004; Segura et al., 2018; Van de Lageweg et al., 2013; Wright and Short, 1984). Given that these megacusp embayments form through an accretionary down-state sequence following storm events, they are hereafter referred to as accretive megacusps. In contrast, megacusp embayments can also form during severe storms when, during high tides, dune erosion can occur in the embayments where the beach is the narrowest, as it is more vulnerable to undercutting by swash (Castelle et al., 2015, 2017a; Thornton, MacMahan, and Sallenger Jr, 2007). As these megacusps form during erosive sequences, they will be hereafter referred to as erosive megacusps. Because of their relative scarcity, their time evolution has received little attention in the literature so far compared to accretive megacusps. In addition, in the frame of the common morphological coupling between the different bedforms in the sand along the wave-exposed coast, the interactions and potential coupling between erosive and accretive megacusps has never been studied.

The 110-km high-energy Gironde sandy coast, SW France, is highly variable alongshore with intense rip currents and prominent accretive megacusp embayments. During the winter 2013/2014 this stretch of coast was exposed to an outstanding series of storm wave events driving the formation of erosive megacusp embayments cutting into the dune all along the coast (Castelle et al., 2015). This stretch of coast is therefore an ideal and representative natural laboratory for studying the time evolution of erosive and accretive megacusps. The present paper builds on the extension of published dataset (Castelle et al., 2014, 2015, 2017a, 2018a), consisting of long-term (70 years) diachronic shoreline data, 3.5-year semi-annual in situ shoreline surveys along the $110 \mathrm{~km}$ of coast since 2014 and 12.5-year monthly to semi-monthly topographic surveys since 2005 . These datasets are for the first time combined to describe the complex temporal and spatial behaviour of erosive and accretive megacusp and to further address the role of potential morphological interaction in governing the coupled system.

\section{FIELD SITE AND DATA COLLECTION}

\section{Gironde Coast}

The open sandy coast of Gironde, located in south west France, extends approximately $110 \mathrm{~km}$ from the Cap Ferret sand spit in the south $(x=0)$ to the Medoc peninsula in the north $(x=110.9$ $\mathrm{km}$ ) (Figure 2a). The coast is meso- to macrotidal with an annual mean spring tidal range of approximately $3.7 \mathrm{~m}$ and a maximum tidal range reaching up to $5 \mathrm{~m}$ during spring tides. Tidal currents are small compared to wave-induced currents, except in the close vicinity of the tip of the Cap Ferret sandspit to the south and in the Soulac area to the north (Figure 2a). The wave climate is energetic and strongly seasonally modulated with a monthlyaveraged significant wave height $\mathrm{Hs}$ ranging from $1.11 \mathrm{~m}$ in July with a dominant W-NW direction to $2.4 \mathrm{~m}$ in January with a dominant $\mathrm{W}$ direction (Castelle et al., 2017a). Incoming winter waves show a strong interannual variability, owing to natural modes of climate variability, primarily the West Europe Pressure Anomaly (WEPA, Castelle et al., 2017b) which explains more than $65 \%$ of the observed winter-mean wave height variability in the Bay of Biscay and the North Atlantic Oscillation which explains $25 \%$ at best. The WEPA positive phase reflects an intensified and southward shifted sea-level-pressure difference between the Icelandic low and the Azores high, driving severe storms that funnel high-energy waves toward western Europe, and particularly in the Bay of Biscay. The dominant W-NW wave climate drives a net longshore drift ranging approximately 200-
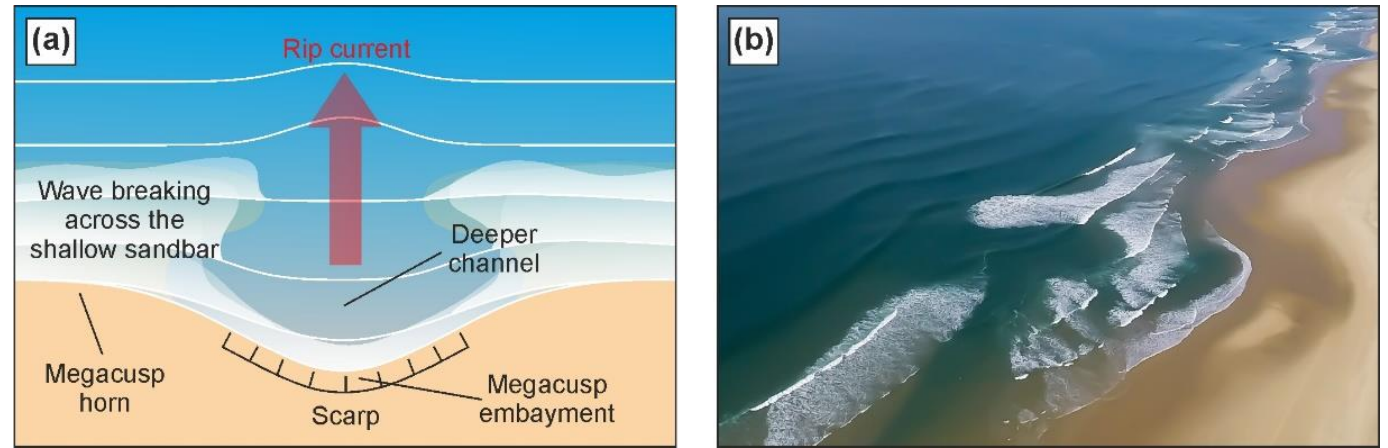

Figure 1. (a) Schematic of a typical transverse bar and rip beach state after Wright and Short (1984) where the alongshore-variable shoreline builds meters seaward behind the welded shallow sandbars where waves primarily break to drive a seaward flowing rip current through the deeper channel that enforces a megacusp embayment. (b) Alongshore-variable beach enforced by the presence of channel rips in SW France (Ph. V. Marieu). 

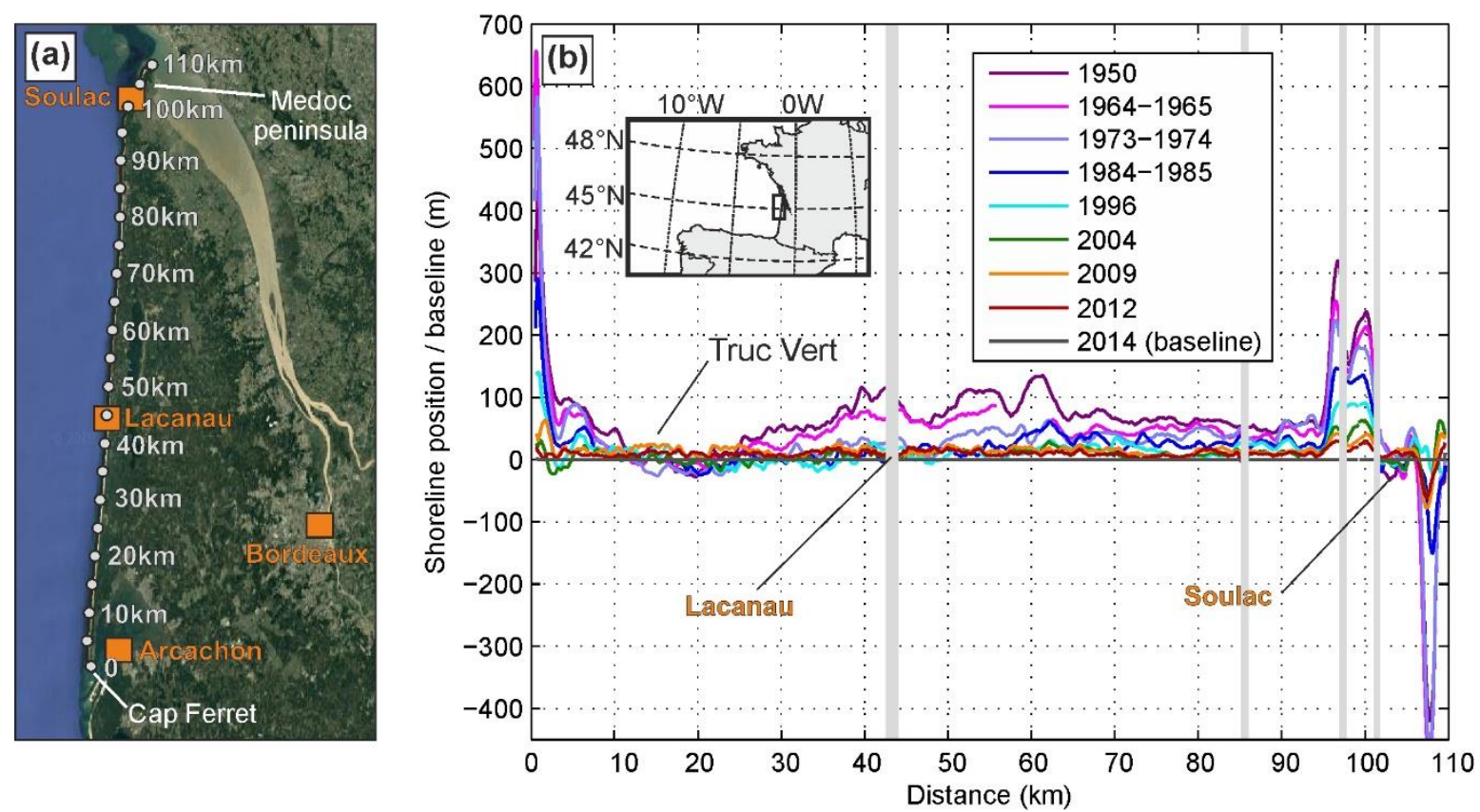

Figure 2. (a) Location map of the 110-km long Gironde coast in SW France with location of the towns of Arcachon, Bordeaux, Lacanau and Soulac. The alongshore distance $\mathrm{x}$ is given in meters with $x=0$ at the tip of the Cap Ferret sandspit at the southern end. (b) Time evolution of shoreline position S from south $(x=0)$ to north $(x=110.9 \mathrm{~km})$ and from 1950 to 2014 with the dates coloured, with the location of Truc Vert beach field site (adapted from Castelle et al., 2018a). Shoreline positions are all given with respect to the shoreline baseline defined in 2014, with positive S meaning that the shoreline is more seaward than in 2014. Hard defences along the coast are indicated by the vertical grey areas. The locations of the coastal resorts of Lacanau and Soulac are also indicated.

$400.103 \mathrm{~m}^{3} /$ year along the Gironde coast which is maximized in the southern part and directed southward (Idier et al., 2013), except in the localized NW-facing sector of Soulac in the north where the longshore drift reverses ( $x>96 \mathrm{~km}$ in Figure 2a).

Beaches are primarily composed of fine to medium quartz sand, and are backed by high and wide aeolian sand dunes (Tastet and Pontee, 1998). These dunes were extensively restored between the $60 \mathrm{~s}$ and the $80 \mathrm{~s}$ through mechanical reshaping together with marram planting (Barrère, 1992). Building on earlier work of Aubie and Tastet (2000), Castelle et al. (2018a) performed a diachronic analysis of georeferenced aerial photographs since 1950 to address long-term shoreline change in SW France, including the Gironde coast. Maximum shoreline evolutions were observed along the sectors adjacent to the inlet and to the estuary mouth, that is, at the Cap Ferret sandspit and the Medoc peninsula with erosion and accretion alternating over time on the timescales of decades (Figure 2b). In the northern sector the maximum mean erosion rate is approximately $5 \mathrm{~m} /$ year and decreases southwards to $1-2 \mathrm{~m} /$ year down to approximately $10 \mathrm{~km}$ south of Lacanau ( $x$ $\approx 30 \mathrm{~km}$ in Figure $2 \mathrm{~b}$ ). Further south, the coast has been relatively stable over the last 70 years along an approximately $20-\mathrm{km}$ long sector. This sector comprises the study site of Truc Vert beach which has been extensively monitored during the last 2 decades (e.g., Castelle et al., 2014, 2015).

The beaches are rip-dominated (e.g., Bruneau et al., 2011) and mostly intermediate double-barred (Castelle et al., 2007). The outer bar is modally crescentic (Almar et al., 2010; Lafon et al.,
2005) while the inner bar is predominantly rip-channelled (Figure 3a). Rip spacing of the inner and outer bars is about $400 \mathrm{~m}$ and $700 \mathrm{~m}$ in the south of the Gironde coast, respectively, and progressively decreases northwards (Castelle et al., 2007). Beach cusps are often observed in the vicinity of the high tide mark (Figure $3 \mathrm{a}, \mathrm{b}$ ), particularly during the beach recovery period of spring-summer-autumn when the beach is steeper around the high tide mark favouring beach cusp development. Almost throughout the year, beaches are highly-variable alongshore with prominent megacusp embayments enforced by the inner-bar rip channels (Figure 3a, c). More recently, erosive megacusps cutting the dunes (Figure 3a, d) formed during the winter of 2013/2014 (Castelle et al., 2015), which was the most energetic winter over most of the Atlantic coast of Europe since at least 1948 (Masselink et al., 2016). The formation of the erosive megacusps during that outstanding winter was enforced by the rhythmic crescentic patterns of the outer bar. The combination of welldeveloped crescentic patterns prior to the winter and persistent shore-normally incident long period storm waves resulted in the formation of intense rip-cell circulations which, combined with extreme mean water levels well exceeding the dune toe elevation, locally eroded the dune. This was extensively described in Castelle et al. (2015, 2017a). All in all, the beaches of the Gironde coast are typically highly variable alongshore all year round with the presence of prominent accretive and erosive megacusps (Figure 3e). 

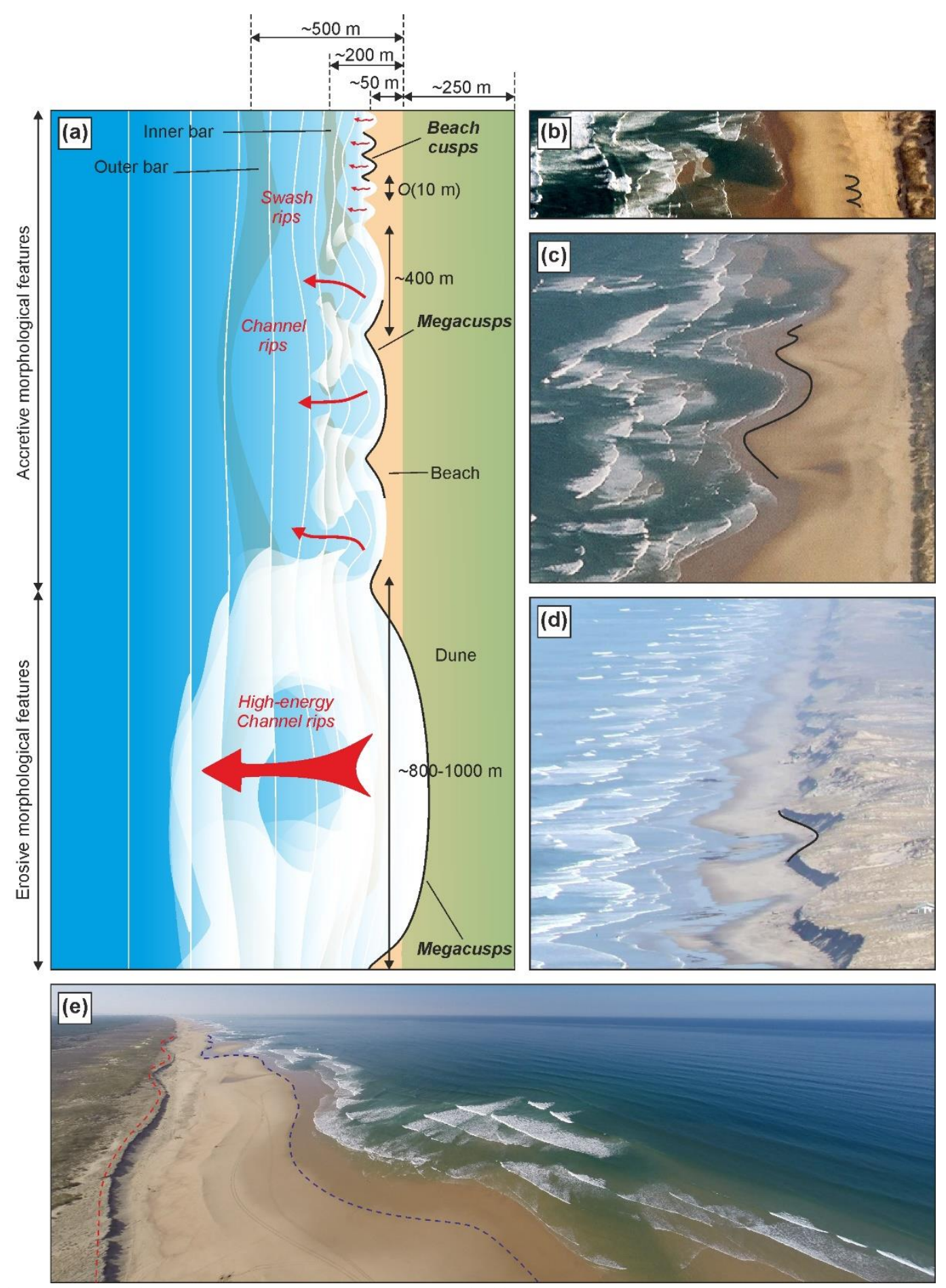

Figure 3. Primary morphological patterns controlling the alongshore variability in the beach and the dune along the double-barred sandy coast of Gironde, SW France. (a) Schematic showing the presence of beach cusps, accretive megacusps and erosive megacusps enforced by swash zone processes, inner-bar rip channels and outer-bar rip channels, respectively, and further illustrated in the field in panels (b) $(\mathrm{Ph}$. P. Larroudé), (c) $(\mathrm{Ph}$. $\mathrm{P}$. Larroudé) and (d) (Ph. J. Lestage). (e) Aerial photograph showing erosive megacusps (dotted red) and accretive megacusps (dotted blue) co-existing at Truc Vert beach on September 26, 2014 and showing uncoupled rhythmicity (Ph. V. Marieu). 


\section{Wave Data}

We use the 69-year wave hindcast detailed in Masselink et al. (2016) and Castelle et al. (2017a, 2017b, 2018b) using the spectral wave model Wave Watch III V14.18 (Tolman, 2014) implemented on a $0.5^{\circ}$ resolution grid covering the whole North Atlantic $\left(80-0^{\circ} \mathrm{W} ; 0-70^{\circ} \mathrm{N}\right)$ forced by the $10-\mathrm{m}$ wind fields of the NCEP/ NCAR reanalysis project (Kalnay et al., 1996), from October 1, 1948 to October 1, 2017. The wave modelling was extensively validated against wave buoys along the entire Atlantic coast of Europe in Masselink et al. (2016). The modelled Hs at the grid point $-1.51^{\circ} \mathrm{W} ; 44.65^{\circ} \mathrm{N}$ in about $50 \mathrm{~m}$ depth was linearly regressed with in situ wave measurements collected by the Candhis buoy located in $54 \mathrm{~m}$ depth at $1.447^{\circ} \mathrm{W} ; 44.653^{\circ} \mathrm{N}$ approximately $15 \mathrm{~km}$ offshore of the Cap Ferret sandspit (Castelle et al., 2014). The comparison of predicted and measured wave height showed a strong linear relationship $\left(R^{2}=0.91, R M S E=\right.$ $0.31 \mathrm{~m})$. Following the definition by Masselink et al. (2014), a storm event was defined as an event where $H s$ exceeds the 0.95 quantile $(H s 95 \%=3.76 \mathrm{~m})$. The initiation of a storm event was defined as the time when the hourly averaged $H s$ exceeded the 0.75 quantile $\left(H_{575 \%}=2.15 \mathrm{~m}\right)$; the end of the storm event was the time when the hourly-averaged $H s$ returned below $2.15 \mathrm{~m}$. Note that the values of $H s 95 \%$ and $H s 75 \%$ computed over 1948-2017 are slightly lower than the values given in Castelle et al. (2015) that were computed over 2005-2014.

\section{Regional Shoreline Data}

Since 2014, the shoreline is surveyed semi-annually along the $110 \mathrm{~km}$ Gironde coast (black line in Figure 2a). An all-terrain vehicle (ATV) equipped with a $2-\mathrm{m}$ accuracy GPS is used to survey the shoreline from south to north between low and midtide. The whole coast was surveyed within approximately 3.5 hours in accreting periods with a smooth and debris-free dune foot throughout the coast to approximately 10.5 hours spanning 2 days when the beach-dune system was severely eroded and strewn with debris and/or with the presence of paleo-soil outcrops (Castelle $e t$ $a l ., 2015)$, typically during the survey of April 3-4, 2014. The shoreline proxy used was the dune foot in eroding sectors (Figure 4a) and the incipient foredune vegetation limit in accreting sectors (Figure 4b). A 2000-m low-pass filtering of the shoreline data was applied to the April 2014 survey in order to filter out the megacusp embayments and to provide the initial shoreline baseline. For each survey the shoreline data were computed with another running average with a window size of $100 \mathrm{~m}$ to remove small-scale features such as beach cusps. The shoreline baseline was subtracted from each shoreline data to result in a band-passed signal between 100 and $2000 \mathrm{~m}$, thus capturing the megacusp embayments cutting the dune, in local shoreline coordinate from $x=0$ at the tip of the Cap Ferret sandspit to $x=110.9 \mathrm{~km}$ at the north of the Médoc peninsula.

\section{Truc Vert Beach Morphological Surveys}

From April 8, 2005 to October 19, 2017, topographic surveys were sampled every 2-4 weeks at spring low tide using a real time kinematic DGPS-equipped (Trimble 56) ATV, with a 1-year gap in 2008, for a total of 215 surveys. Between 2005 and 2008, the alongshore extent of the surveys was $350 \mathrm{~m}$, then was extended to $750 \mathrm{~m}$ in 2008 and then again to $1500 \mathrm{~m}$ in 2012 . This $1500-\mathrm{m}$ alongshore coverage was designed to encompass approximately
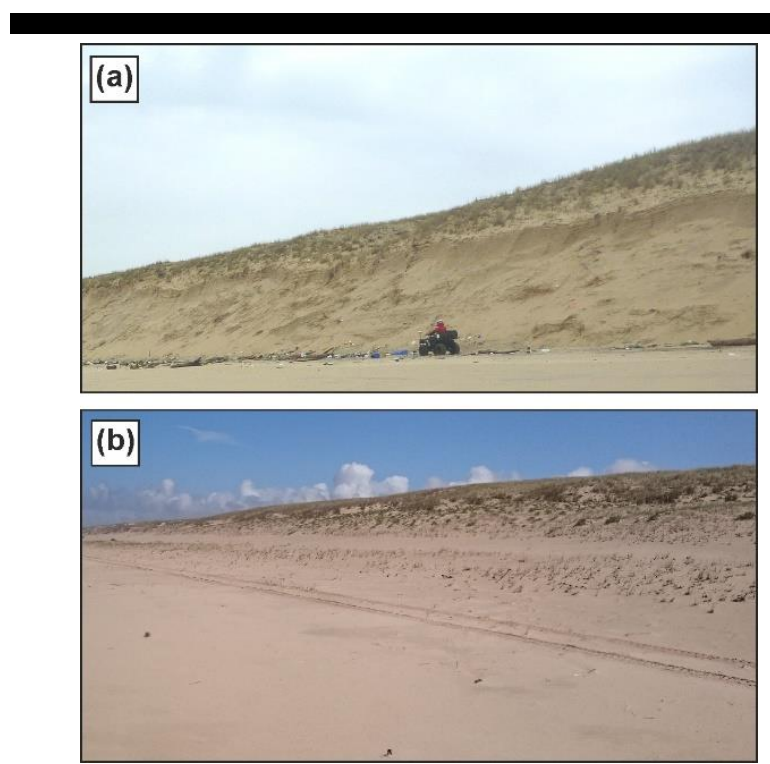

Figure 4. Regional shoreline data collection using a GPS-equipped ATV. The ATV is also equipped with a 3-m stick to drive approximately $2 \mathrm{~m}$ from the real shoreline position in order to protect from from scarp collapse in severely eroding areas. The shoreline proxy used is (a) the dune foot in eroding sectors (Truc Vert beach sector on April 3, 2014, $\mathrm{Ph}$. B. Castelle) and (b) the vegetation limit in accreting sectors (Truc Vert beach sector on May 2, 2017, Ph. B. castelle, see the ATV wheel mark to the left of the incipient foredune.

3-4 inner-bar rip-channel wavelengths. Anisotropic kriging interpolation was performed on a regular grid with an alongshore and cross-shore mesh size of $20 \mathrm{~m}$ and $2 \mathrm{~m}$, respectively. The digital elevation model was further averaged alongshore to compute the mean profile from which the beach-dune volume and the shoreline position using different proxies can be computed. For a detailed description of the survey and interpolation methods, the reader is referred to Castelle et al. (2014).

The total beach-dune volume per beach width was computed by integrating all positive elevations above mean sea level (MSL) with the total volume at the start of the survey period set to 0 . The beach and dune volumes were further discriminated by setting an arbitrary vertical threshold based on visual observation of average foredune vegetation limit prior to the 2013/2014 winter $(z=6 \mathrm{~m}$, Castelle et al., 2017a). A visual inspection of beach topographies indicates that the signature of megacusp presence is maximized, on average, for the iso-contour $z=2 \mathrm{~m}$. The 2-m and $6-\mathrm{m}$ elevation shoreline data $S_{2 m}$ and $S_{6 m}$ were therefore computed to address the dynamics of accretive and erosive megacusps, respectively. The mean and alongshore standard deviation of $S_{2 m}$ and $S_{6 m}$ were further computed to give a measure of beach and dune erosion/accretion periods and alongshore variability, respectively.

\section{RESULTS}

Dune Scarp and Large-scale Megacusp Embayment Change Since the 2013/2014 Winter

Figure 5 shows the time evolution of the shoreline cross-shore deviation from the 2014 shoreline baseline as a function of 
alongshore distance along a $68-\mathrm{km}$ long section of the Gironde coast, where the erosive megacusps are the most prominent. Results show that, compared to the mean shoreline position in April 2014 at the end of the 2013/2014 winter (thick blue line in Figure 5a), 3.5 years after the shoreline accreted by approximately $10 \mathrm{~m}$ on average in the southern sector (thick red line in Figure 5a). The accretion decreases northwards until no significant accretion is found north of $x \approx 65 \mathrm{~km}$. Cuspate-type rhythmic dune erosion scarps (erosive megacusp embayments) were striking along the Gironde coast at the end of the 2013/2014 (thin blue line in Figure 5a). The alongshore spacing of these shoreline rhythms varied between approximately $500 \mathrm{~m}$ and 2000 $\mathrm{m}$ from north to south (Figure 6a). The cross-shore amplitude also decreased from the south (10-20 $\mathrm{m}$ on average) to the north (5-10 $\mathrm{m}$ on average) peaking at approximately $38 \mathrm{~m}$ at $x \approx 19.5 \mathrm{~km}$. The megacusp embayments were still readily present 3.5 years after, at the end of 2017 (thin red line in Figure 5a), although their amplitude mostly halved along the entire sector. Their rhythmicity did not change substantially, and was therefore less pronounced than at the end of the 2013/2014 winter (Figure 6b).

Figures $5 \mathrm{~b}$ and $5 \mathrm{c}$ focus on two 10-km long 2014-2017 accreting and stable sectors, respectively, and provide insight into
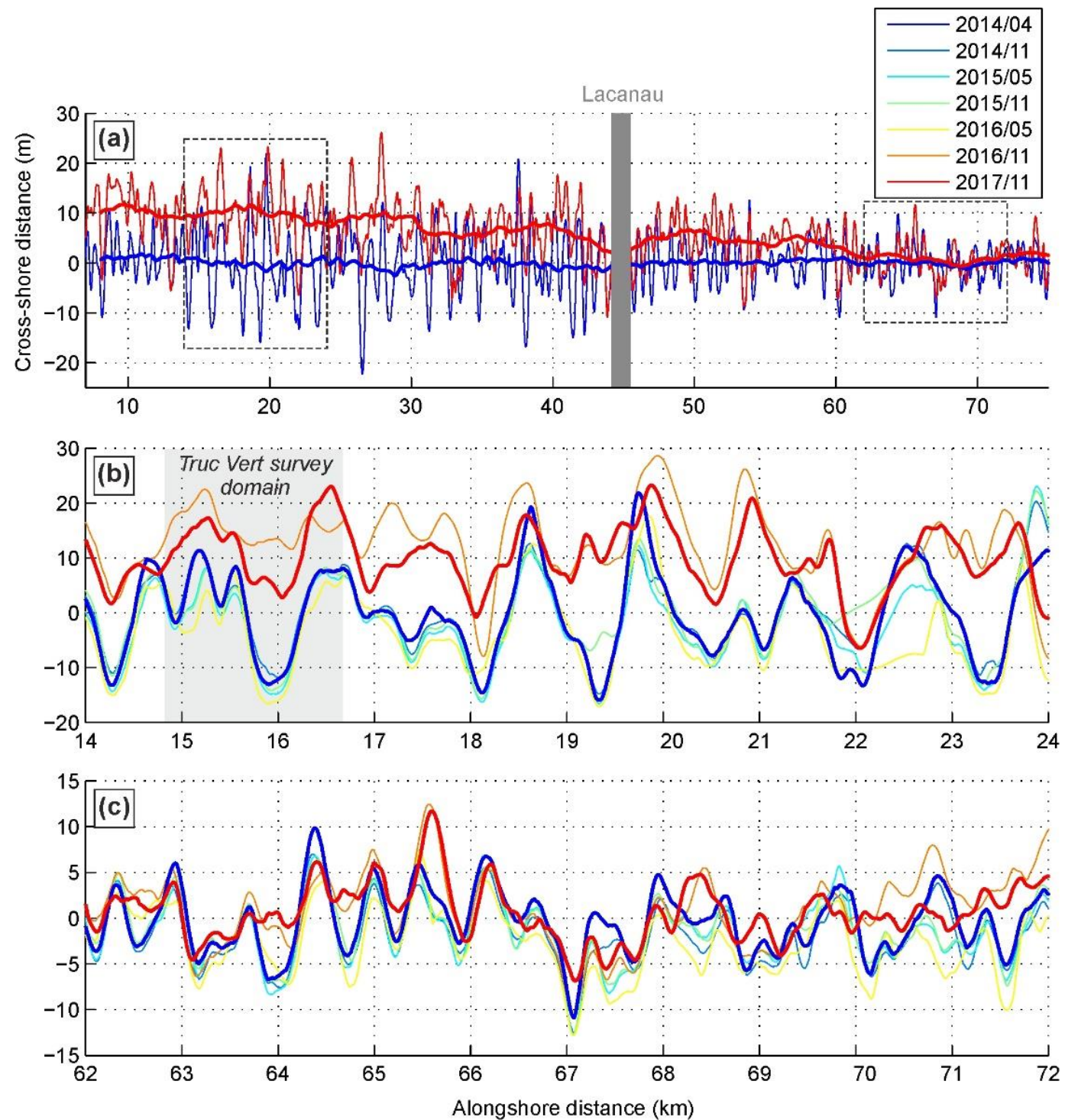

Figure 5. Cross-shore deviation from mean shoreline measured on April 2014 as a function of alongshore distance (positive northwards) with colour indicating the date. (a) Deviation along the section $7 \mathrm{~km}<x<75 \mathrm{~km}$ where erosive megacusps were prominent at the end of the $2013 / 2014$, the thick lines being a moving average on $5 \mathrm{~km}$ and the vertical grey bar indicating of the coastal resort of Lacanau. Only the initial (April 2014) and final (November 2017) dates shown. The two dashed black boxes show the areas zoomed (b) in the vicinity of Truc Vert beach (shown by the light grey box) in a recovering sector and (c) in a northern sector where recovery from the 2013/2014 winter is subtler. 

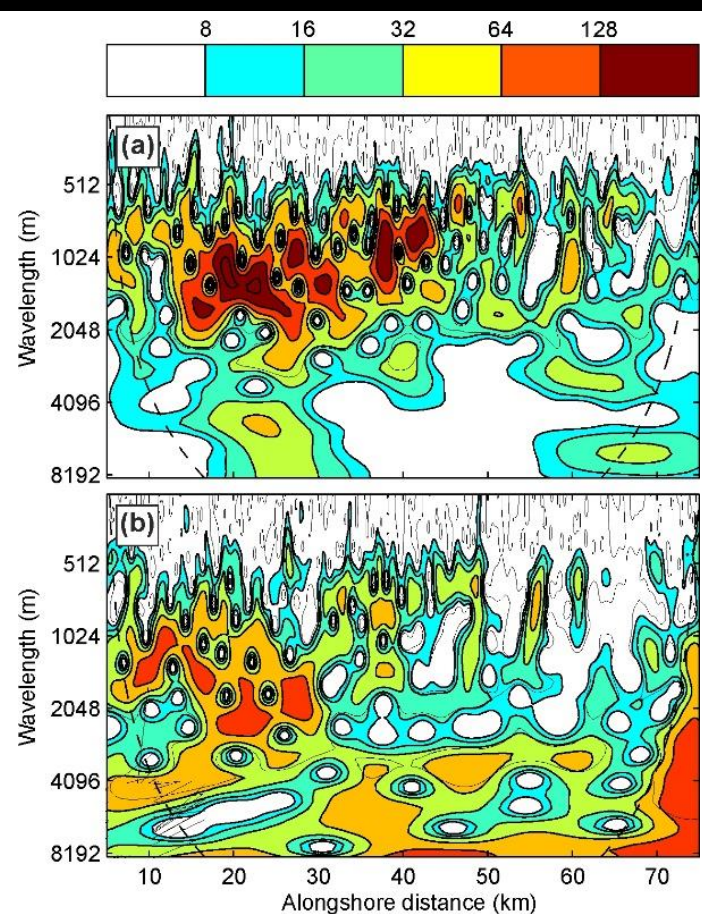

Figure 6. Local wavelet spectrum of the shoreline deviation from the mean shoreline normalized by the variance with the dashed black contours depicting the cone of influence for (a) the initial survey on April 2014 and (b) the final survey on November 2017.

the time evolution of shoreline position through the 7 shoreline surveys. Results show that, in the rapidly recovering sectors (Figure 5b) the cross-shore amplitude of the megacusps primarily decreased as a result of (1) the erosion of the megacusp horns during the winters of 2014/2015 and 2015/2016 (e.g., at $x=15.2$, $19.8,22.5 \mathrm{~km}$ in Figure $5 \mathrm{~b}$ ) and particularly (2) the rapid shoreline accretion owing to incipient foredune development in the megacusp embayments that mostly occurred during the springsummer-autumn periods of 2016 and 2017 (e.g., at $x=16,19.3$, $23.4 \mathrm{~km}$ in Figure 5b). In eroding sectors, similar patterns were observed, although shoreline accretion in the megacusp embayments was less pronounced than in the accreting sectors. In addition, the dune further eroded even locally within the megacusp embayments (e.g., at $x=64.8,70.2,71.5 \mathrm{~km}$ in Figure $5 \mathrm{c})$. Noteworthy, the overall geometry of the megacusps did not show any significant asymmetry throughout the study period. The centre of the embayments remained located roughly equidistant from its horns, and no alongshore migration of the megacusps was captured. Overall, the megacusp embayments were still observed even 3.5 years after the outstanding winter of 2013/2014, although their cross-shore amplitude decreased.

\section{Time Evolution of Megacusp Embayments at Truc Vert Beach}

Figure 7 shows 2 representative beach-dune morphologies of Truc Vert beach. On April 29, 2013, prior to the 2013/2014 winter, Truc Vert showed a wide beach and an untouched and reasonably alongshore-uniform foredune. In contrast, the subaerial beach was largely variable alongshore with 5.5 well-developed megacusps along approximately $1.6 \mathrm{~km}$ of beach with a mean cross-shore amplitude of $15-20 \mathrm{~m}\left(\operatorname{std}\left(S_{2 m}\right)=6.23 \mathrm{~m}\right)$. These megacusp embayments were readily coupled with the rip-

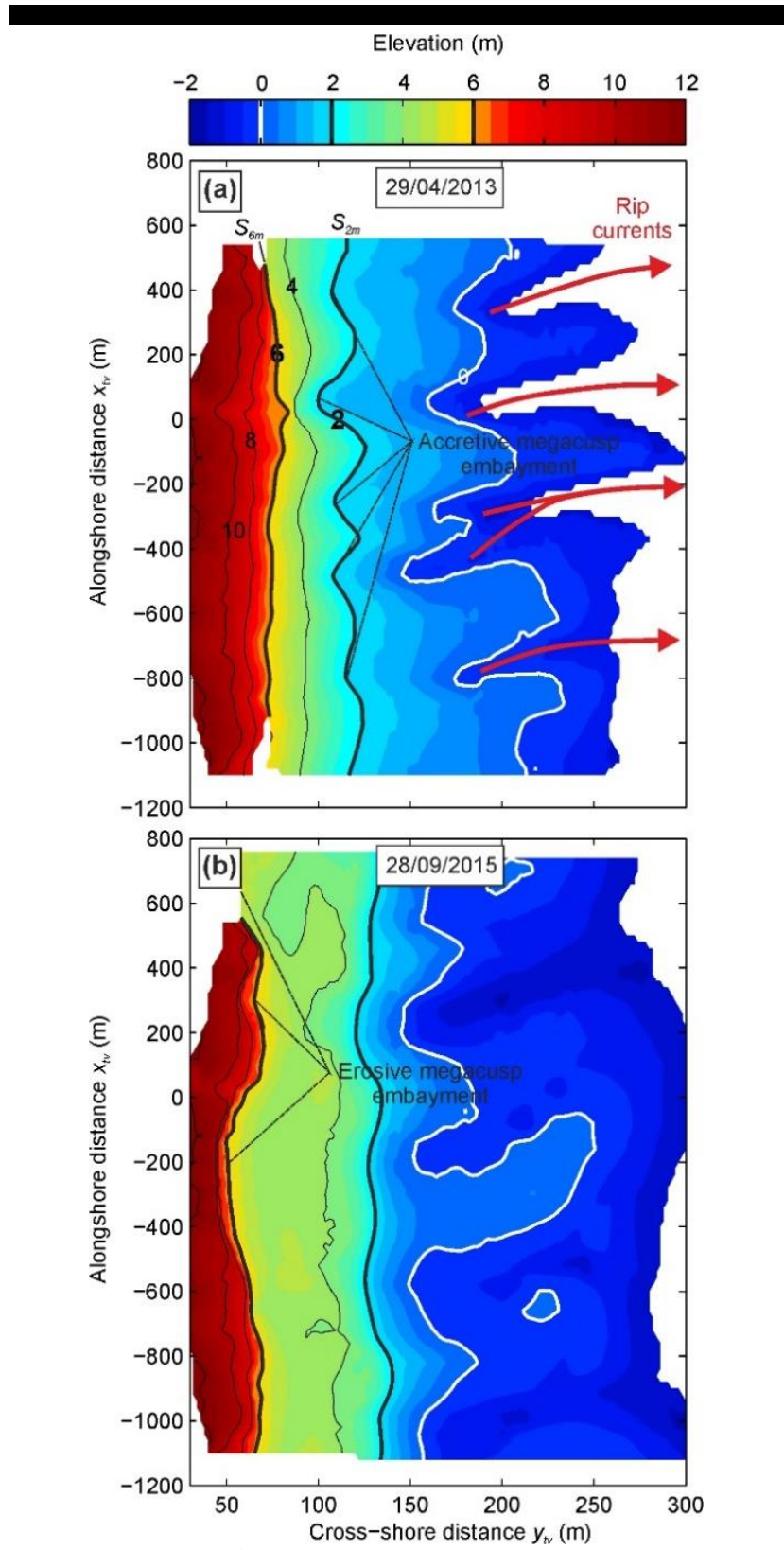

Figure 7. Example of Truc Vert beach survey with colour bar indicating elevation above MSL in metres. (a) Beach survey prior the 2013/2014 winter showing a relatively alongshore-uniform dune foot but an alongshore-variable beach morphology with five distinct accretive megacusps enforced by the inner-bar rip channels. (b) Beach survey after the 2013/2014 winter showing co-existing accretive megacusp and a large-scale erosive megacusp system cutting the dune with a crossshore amplitude of approximately $20 \mathrm{~m}$. 
channelled inner bar (Figure 7a) through which intense rip currents are known to flow offshore preferably between mid and low tide (Bruneau et al., 2009). This contrasts with the beachdune morphology on September 28, 2015 (Figure 7b). Here, accretive megacusps coupled to the inner bar rip channels are also observed, although less developed $\left(\operatorname{std}\left(S_{2 m}\right)=4.80 \mathrm{~m}\right)$ than on April 29, 2013, with a more pronounced bermed profile and larger mean spacing. A striking pattern is the strong alongshore variability in dune erosion pattern that was enforced by the outer crescentic sandbar (with a wavelength of approximately $800 \mathrm{~m}$ at Truc Vert during that winter, Castelle et al., 2015) forming megacusp embayments cutting the dune. The major megacusp embayment located in the centre of the domain at Truc Vert had an amplitude of approximately $20 \mathrm{~m}$ and $600 \mathrm{~m}$ in the cross-shore and alongshore directions, respectively $\left(\operatorname{std}\left(S_{6 m}\right)=6.83 \mathrm{~m}\right)$. In contrast, the dune eroded by only a couple of metres on average across the megacusp horn.

Figure 8 shows the 12.5 -year time series of wave conditions and morphological response at Truc Vert. Results show a large seasonal modulation of $H s$ with more wave energy arriving at the coast during boreal winters. A total of 137 storm events were identified from December 2005 to December 2017, i.e. 11 per year on average, with the majority (62\%) of the storm events occurring in winter (DJFM) associated with the largest peak storm $H s$ ( $83 \%$ in NDJFMA). The mean peak storm $H s$ was 5.41 $\mathrm{m}(\mathrm{std}=1.14 \mathrm{~m})$. The winter of 2013/2014 was not only the most energetic over the period since 2005, but also since at least 1948 along the entire Atlantic coast of Europe south of $55^{\circ} \mathrm{N}$ (Masselink et al., 2016). During that winter, the Gironde coast was exposed to only 9, but long, storm events. For instance, the storm between January 22 and February 17, 2014 was the longest storm event the Gironde coast was exposed to since at least 1948. A prominent pattern is the large inter-annual variability in winter wave height. Over the 12 winters studied here (2006-2017) the winter-mean $H s$ varied from $1.74 \mathrm{~m}$ (winter of 2010/2011) to 3.06 $\mathrm{m}$ (winter of 2013/2014) m. Corroborating earlier work (Castelle et al., 2017b), this strong inter-annual variability was primarily linked with WEPA. With a correlation coefficient $R$ of +0.87 , WEPA explains $76 \%$ of the observed winter-mean wave height variability at Truc Vert between over these 12 winters. During that period, 2 winters stand out: the 2013/2014 (WEPA index of +2.67 ) and 2015/2016 (WEPA index of +1.75 ) winters ranking $1^{\text {st }}$ and $5^{\text {th }}$ in terms of winter-mean $H s$, respectively, over 1948 2017.

Figure $8 \mathrm{~b}$ shows the time series of the beach-dune volume at Truc Vert over the same period. The beach-dune volume shows striking seasonal cycles (Figure 5b) with, on average, the beach eroding during approximately 4 months (NDJF) and recovering during the 8 following months (Castelle et al., 2017a), with an average amplitude of approximately $80 \mathrm{~m}^{3} / \mathrm{m}$. The beach-dune volume also shows large interannual variability, with an amplitude that even exceeds that of the seasonal variability (see also Robinet et al., 2016). Amongst the 10 winters addressed here, the 2013/2014 winter was outstanding in term of storm-driven erosion with approximately $180 \mathrm{~m}^{3} / \mathrm{m}$ of sand removed from the system, while the 2015/2016 winter drove the second most intense erosion with approximately $120 \mathrm{~m}^{3} / \mathrm{m}$ of eroded sand (Figure $8 \mathrm{~b}$ ). The alongshore-averaged $2-\mathrm{m}$ shoreline $\bar{S}_{2 m}$ shows similar patterns (Figure 8e), which is not surprising because this shoreline proxy correlates well with the total beach volume at Truc Vert beach $(R>0.9$, Robinet et al., 2016). In contrast, the alongshore-averaged 6-m shoreline $\bar{S}_{6 m}$ corresponding to the alongshore-averaged dune foot position does not show any seasonal signal (Figure 8c). Instead, while a slow accretion was observed prior to the 2013/2014 winter, during that winter $\bar{S}_{6 m}$ retreated by approximately $17 \mathrm{~m}$ over 3 months (Figure $8 \mathrm{c}$ ). Subsequently, the 6-m elevation shoreline accreted at a quasisteady rate, likewise the situation prior to the 2013/2014 winter, with no apparent impact of the 2015/2016 energetic winter.

Below we describe the time evolution of the alongshore variability in the 6-m and 2-m elevation shorelines, which gives information on the erosive and accretive megacusp, respectively. The time evolution of $S_{6 m}$ (Figure 5d) clearly shows the formation of an erosive megacusp centred at $x_{t v} \approx-250 \mathrm{~m}$ with a cross-shore amplitude of approximately $25 \mathrm{~m}$ during the 2013/2014 winter (largest WEPA index on record: +2.67). The subsequent winter (2014/2015) was characterised by low storm intensity and low WEPA index (-0.24). However, the beach level was so low that, even if hardly visible in Figure 8, slight dune erosion occurred (Figure 5b). During the subsequent winter (2015/2016) ranking $5^{\text {th }}$ since 1948 , substantial dune erosion was observed at the megacusp horns (see at $x_{t v}=-1000 \mathrm{~m}$ and $200 \mathrm{~m}$ in Figure 8d) where little or no erosion had occurred during the winter of 2013/2014. Therefore, while the megacusps were still observed even almost 4 years after their formation during the 2013/2014 winter, their decrease in amplitude was primarily driven by the $2015 / 2016$ winter (see decrease in $\operatorname{std}\left(S_{6 m}\right)$ in Figure 8 c) owing to the erosion of the megacusp horns. No alongshore migration of the megacusp embayments were observed, in line with the largescale observations in Figure 5. The only notable exception is at the formation stage during the 2013/2014 winter, when the centre of the megacusp embayment migrated downdrift by approximately $200 \mathrm{~m}$ between January and March 2014 (Figure 8d, see also Castelle et al., 2015).

The time evolution of the 2-m elevation shoreline $S_{2 m}$ shows patterns that contrast with $S_{6 m}$ (Figure 8f). Prior to the 2013/2014 winter, megacusp embayments were primarily observed during the recovery period (AMJJASO) with a clear downdrift (southerly) migration on the order of $2 \mathrm{~m} /$ day. The average wavelength was $300-400 \mathrm{~m}$, although with a large variability. These wavelength and alongshore migration observations are in line with the observations of inner-bar rip channel downdrift migration along the coast through satellite imagery in Lafon et al. (2002). Although often still subtly present, accretive megacusps tend to decrease in amplitude and to be reshaped during the winter periods. After the 2013/2014 winter, the 2-m elevation shoreline dynamics substantially changed. First, the dominant average wavelength became approximately $800 \mathrm{~m}$. Second, the alongshore variability was not smoothed out during the 3 subsequent winters. Instead, patterns continued to migrate downdrift all year round and with a readily lower rate of approximately $1 \mathrm{~m} /$ day. The only notable exception is the updrift migration of a seaward bulge in the shoreline during 2017 at the $x_{t v} \approx-800 \mathrm{~m}$. Therefore, the 2013/2014 winter strongly altered the $2-\mathrm{m}$ shoreline dynamics and, in turn, that of the accretive megacusps during the 4 subsequent years. 

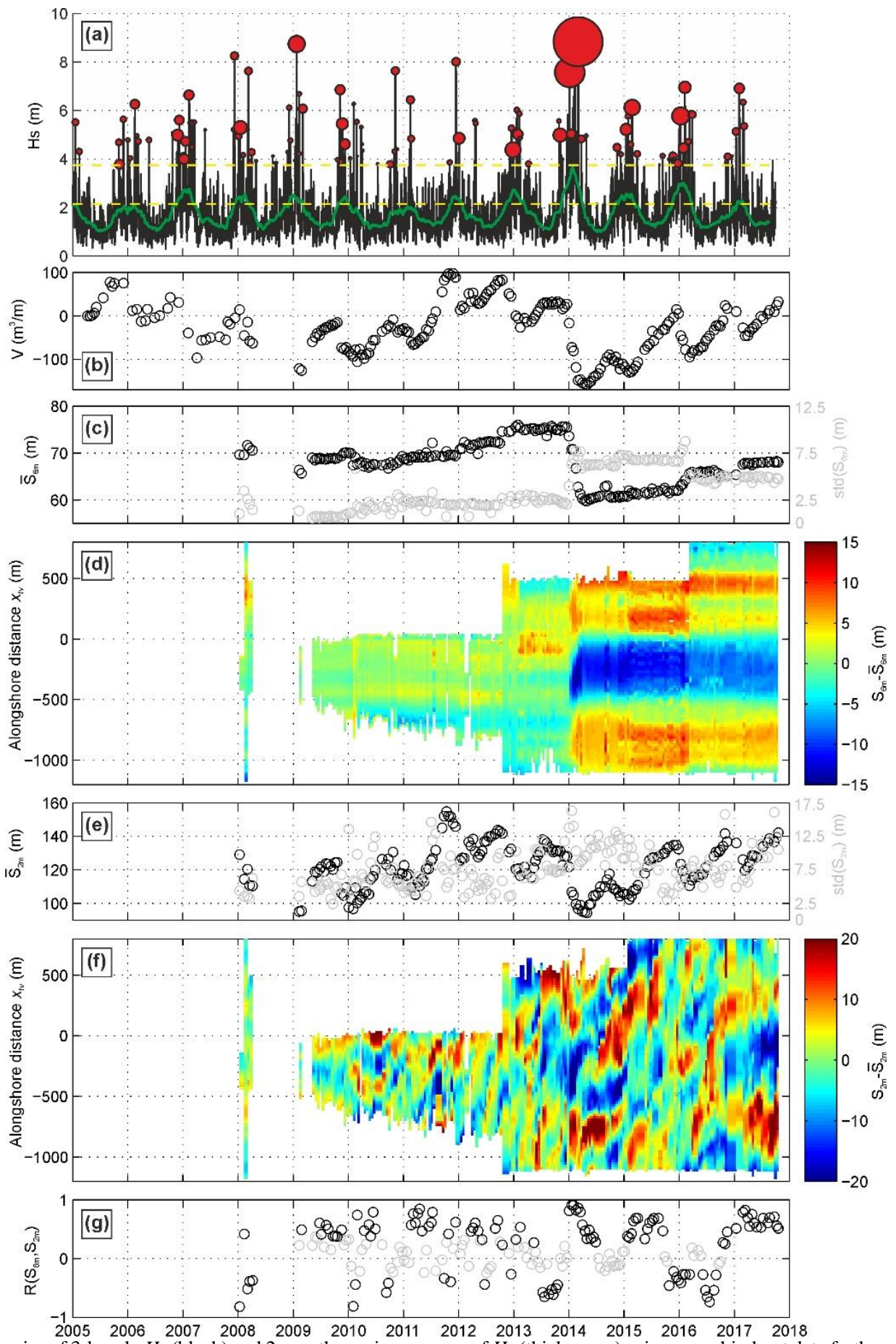

Figure 8. (a) Time series of 3-hourly $H s$ (black) and 2-month moving average of $H s$ (thick green) using wave hindcast data further corrected via linear regression with buoy measurements. Based on Masselink et al., (2014) and Castelle et al. (2015) the red bubbles are storm events (Hs > ${ }_{595 \%)}$, whereby the size of the bubbles is proportional to storm duration based on $H s_{75 \%}$ cut-off either size of storm maximum. $H s_{99 \%}, H s_{95 \%}$ and $H s_{75 \%}$ are indicated by the horizontal yellow dashed lines. Time series of (b) beach-dune volume above MSL; (c) mean (black) and longshore standard deviation (grey) of the 6-m elevation shoreline $\bar{S}_{6 m}$ and $\operatorname{std}\left(S_{6 m}\right)$, respectively; (d) deviation of the 6-m elevation shoreline from the mean $S_{6 m}-\bar{S}_{6 m}$; (e) mean (black) and longshore standard deviation (grey) of the 2-m elevation shoreline $\bar{S}_{2 m}$ and $\operatorname{std}\left(S_{2 m}\right)$, respectively; (f) deviation of the 2-m elevation shoreline from the mean $S_{2 m}-\bar{S}_{2 m}$; (g) correlation coefficient between $S_{6 m}$ and $S_{2 m}$ with grey circles indicating correlation that is not statistically significant at the $95 \%$ level. 


\section{DISCUSSION}

Observations show that two types of megacusps co-exist along most of the 110-km Gironde coast. Accretive megacusps on the upper beach are essentially enforced by the dynamics of inner-bar rip channels developing as a down-state morphological sequence. These megacusps with a spacing of $\mathrm{O}(100 \mathrm{~m})$ have a typical lifetime of a few months, tend to migrate downdrift by $\mathrm{O}(1 \mathrm{~m} /$ day $)$ and, before the 2013/2014 winter, were typically smoothed out by severe, preferably obliquely-incident, storm waves. In contrast, erosive megacusps are primarily enforced by the outer-bar morphology guiding intense rip currents during severe, shorenormally-incident, long-period storm waves (Castelle et al., 2015). These erosive megacusps have therefore a larger spacing potentially exceeding $1 \mathrm{~km}$ in the southern part of the Gironde coast. In this study, only one event of erosive megacusp formation was observed along almost the entire coast, which occurred during the 2013/2014 winter. Almost 4 years after, erosive megacusp embayments are still part of the landscape although the cross-shore amplitude has been approximately halved. As shown in Figure 9a-b, the onset of foredune recovery was not observed at the centre of the largest megacusp embayments despite dune scarp slumping and beach recovery through onshore sediment transport. Foredune recovery was also not observed further north where chronic erosion is intense. Our results therefore suggest that erosive megacusps may have a lifetime exceeding 10 years. A visual inspection of historical photographs shows the rare occurrence of such erosive megacusps a few decades ago along certain sectors (Figure 9c-d). However, along these sectors the shoreline has eroded by approximately $50 \mathrm{~m}$ since then (Figure 2) and it is impossible to estimate their initial cross-shore amplitude or the lifetime of these patterns. It will be important to address when the erosive megacusps that formed during the 2013/2014
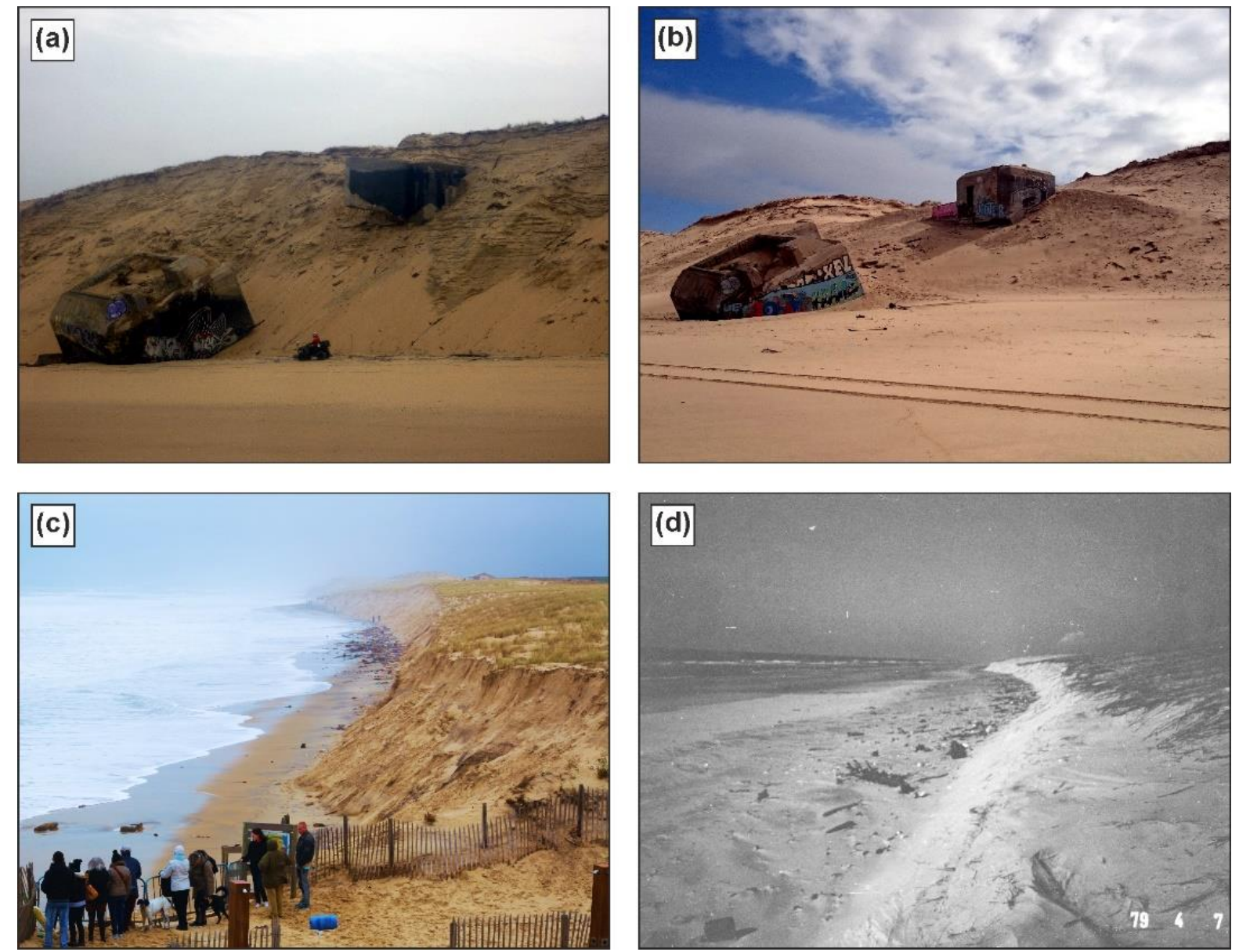

Figure 9. (a) 12+m-high erosion scarp uncovering World War II German bunkers with the ATV giving the scale (April, 2014, Ph. B. Castelle) evolving into (b) a slumped dune scarp three years after (May 2017, Ph. B. Castelle). Although the beach rose by a few metres, the dune system did not recover. In addition, note that a piece of the bunker located on the top of the dune detached between (b) and (a). (c) Photograph of a large megacusp embayment north of Lacanau in March 2014 (Ph. J. Lestage), and (d) north of Lacanau on April 7, 1979 (LCHF, 1979) clearly showing the presence of an erosive megacusp with similar morphological characteristics to those observed during the winter 2013/2014. 
winter will be smoothed out and how the timing varies along the coast depending on the local chronic erosion rate. In this frame, Structure from Motion approach via low-cost flexible and lightweight UAVs, or airborne LiDar, will provide highresolution remotely-sensed beach-dune morphology data on sufficiently large spatial scales to address this problem. Such a monitoring program has been implemented since 2015 along 4 $\mathrm{km}$ of beach-dune system at Truc Vert (Laporte-Fauret et al., 2019), and 2 other sites further north along the Gironde coast.

The 2013/2014 winter drove the formation of erosive megacusps, which dramatically changed the dynamics of the 2-m elevation shoreline. Prior to that winter accretive megacusps had a mean spacing of approximately $400 \mathrm{~m}$, forming preferably at the end of the winter and migrating downdrift by approximately $2 \mathrm{~m} /$ day on average, in line with Lafon et al. (2002). These megacusps were typically smoothed out during winter storms, therefore having a typical lifetime of less than one year. During the 2013/2014 winter, the 2-m shoreline coupled to the erosive megacusps (6-m elevation shoreline) as evidenced by the high $R\left(S_{2 m}, S_{6 m}\right)$ in Figure $8 \mathrm{~g}$, therefore with a spacing increasing to approximately $1000 \mathrm{~m}$. It is important to note that at the end of the 2013/2014 winter the discrimination between erosive and accretive megacusps was blurred as the whole beach had lowered by approximately $2-3 \mathrm{~m}$, and by more than $4 \mathrm{~m}$ in the alignment of the megacusp embayment. Therefore, the 2-m elevation shoreline $S_{2 m}$ did not capture accretive (bermed) megacusp as the bermed profile only started forming in spring-summer 2014. In contrast with the erosive megacusps, the upper beach megacusps subsequently migrated downdrift, although with a readily slightly lower rate than that prior to the 2013/2014 winter. This beach alongshore variability kept the same primary wavelength $(\sim 800$ $\mathrm{m})$ and was not smoothed out during the subsequent winters. This resulted in an alternating in-phase and out-of-phase coupling between $S_{2 m}$ and $S_{6 m}$ alternating over time (Figure $8 \mathrm{~g}$ ). Of note, the in-phase and out-of-phase coupling pattern before the 2013/2014 winter was more irregular (Figure 8g), which may be explained by a combination of less pronounced erosive megacusp variability and a shorter alongshore coverage of the topographies. Figure 10 provides insight into this in-phase and out-of-phase coupling. Clearly, after the 2013/2014 winter two modes of alongshore variability was observed in $S_{2 m}$. An alongshore variability with a spacing of approximately $800 \mathrm{~m}$ reminiscent of the formation of the megacusp embayments formed during the 2013/2014 winter, and a more subtle variability with a mean wavelength of $400 \mathrm{~m}$ enforced by the inner-bar rip channelled. This is illustrated in Figure 10 showing a typical in-phase (Figure 10a) and out-of-phase (Figure 10b) coupling, which both show the complex links between the two types of variability. This coupling behaviour somewhat contrasts with the other types of coupling observed in the nearshore system where it is the more offshore pattern that enforces a rhythmicity in the more inshore pattern (e.g., Castelle et al., 2010a, 2010b; Price and Ruessink, 2013; Price et al., 2013; Price, Ruessink, and Castelle, 2014; Sonu, 1973). The only notable exception is described in Holland and Holman (1996) who observed the formation of shorter scale cusps with spacings of approximately half that of the most welldeveloped cusps located at a higher (more onshore) beach level. In their case, the morphological response of the lower cusps was hypothesized to be morphologically forced by the higher, larger
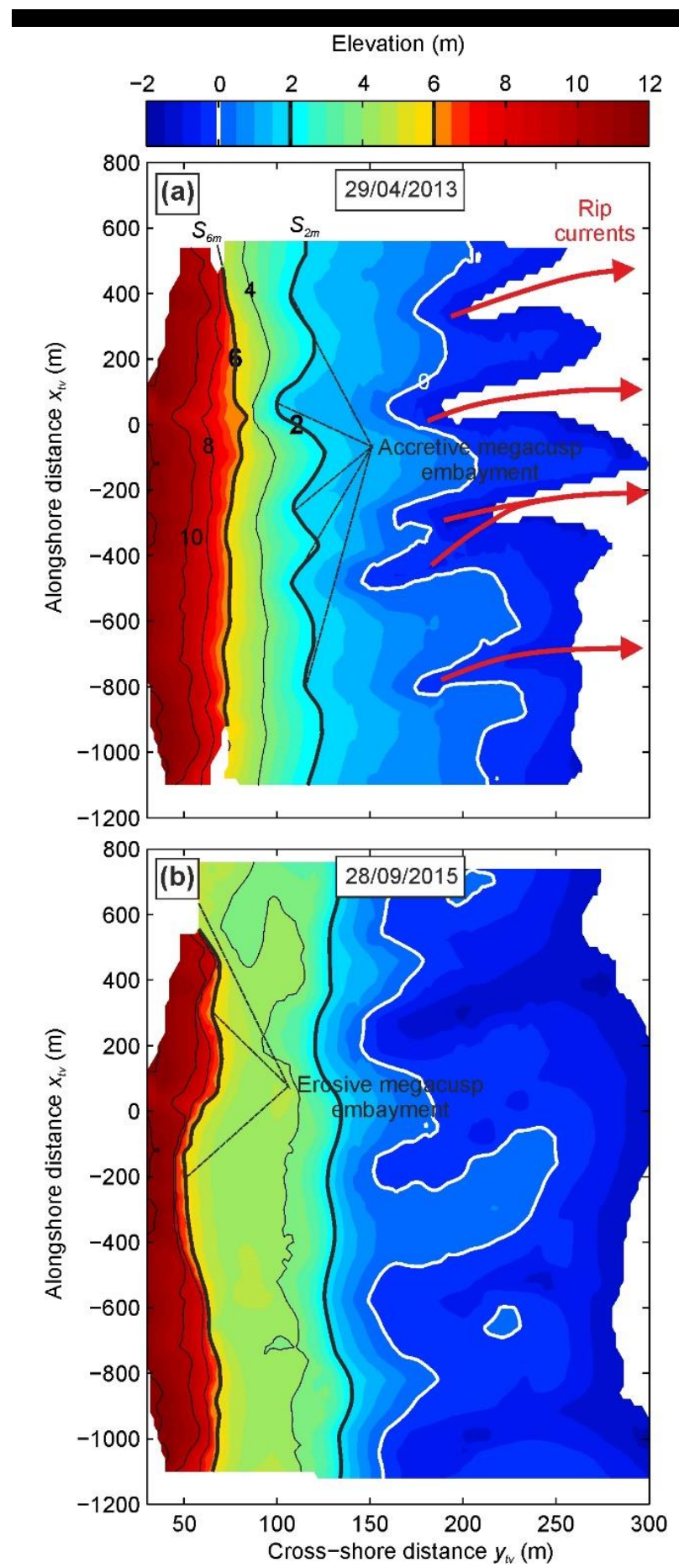

Figure 10. Example of Truc Vert beach survey with colour bar indicating elevation above MSL in metres. (a) Beach survey prior the 2013/2014 winter showing a relatively alongshore-uniform dune foot but an alongshore-variable beach morphology with five distinct accretive megacusps enforced by the inner-bar rip channels. (b) Beach survey after the 2013/2014 winter showing co-existing accretive megacusp and a large-scale erosive megacusp system cutting the dune with a crossshore amplitude of approximately $20 \mathrm{~m}$. 
cusps. Herein, the erosive megacusps are hypothesized to morphologically force an alongshore variability in the height of the lower (more offshore) in beach elevation. Beach patterns subsequently migrate downdrift freely, while the erosive megacusp cutting the dune remain at the same location, resulting in a persistent coupling with a time-varying phase lag.

These results show that along beaches with rip-channel bathymetries it is necessary to design the survey domain such as a few rip-channel wavelengths are covered. Using survey domains that are too narrow prevents the alongshore variability in beach dynamics from being addressed and, in turn, can significantly bias the analysis of the time evolution of the alongshore-averaged beach parameters, such as shoreline position, beach width and volume. Along the high-energy beaches of SW France, survey domains extending at least $1000 \mathrm{~m}$ alongshore are therefore required to robustly address beach and dune changes. Indeed, here the data collected prior to October 2012 along a stretch of coast $\leq \sim 800 \mathrm{~m}$ does not allow a thorough assessment of the dynamics of the megacusps and would not have fully captured both the formation of the erosive megacusp cutting the dune and the nearby untouched foredune during the 2013/2014 winter. Truc Vert beach is surveyed semi-monthly, which is frequent enough to capture beach changes from the timescales of seasons to decades through interannual variabilities. This is also sufficient to calibrate empirical shoreline/volume models that can successfully hindcast 1-5-year shoreline/volume variability (Splinter, Turner, and Davisdson, 2013) and can be further used to address shoreline change at the scale of a single storm (Davidson, Splinter, and Turner, 2013; Splinter et al., 2014; Yates et al., 2009). Such a sampling common for different coastal sites is also critical to robustly address the variability and complexity of beach response and subsequent pattern and magnitude of recovery depending on wave exposure and geological inheritance (Dodet et al., 2019; Masselink et al., 2016). As far as long-term monitoring of high-energy sandy beaches along open and quasistraight sandy coasts is concerned, it is therefore recommended to perform surveys extending a few rip-channel wavelengths sampled monthly.

Results show that an outstanding winter, such as that of 2013/2014 which was the most energetic since at least 1948, can dramatically alter the coastal landscape and impact the beachdune dynamics on the time scale of at least a few years, to potentially decades for the megacusp embayments cutting the dune. Most of the existing long-term wave model forecasts indicate that there will be no increase in winter wave in the northeast Atlantic, or even a decrease regardless the emission scenario (Hemer et al., 2013; Wang, Feng, and Swail, 2014). However, over the last decades, the increased winter-mean wave height, variability and periodicity along the Atlantic coast of Europe resulted in more frequent high-energy winters (Castelle $e t$ al., 2018b). It is therefore still likely that such outstanding winters will repeat in the future which, in the context of chronic erosion owing to the dearth of sediment supply from the inner shelf and rivers and sea level rise, suggest that beach-dune behaviour may further change in the near future along the Gironde coast. Our study suggests that performing surveys extending a few ripchannel wavelengths sampled monthly is relevant to address the response of high-energy beaches along open and quasi-straight sandy coasts, which could become a common approach to such sites within the national coastal monitoring service Dynalit (www.dynalit.fr).

\section{CONCLUSIONS}

We used long-term (70 years) diachronic shoreline data and semi-annual 3.5-year in situ shoreline surveys along approximately $110 \mathrm{~km}$ of coast since 2014, combined with 12.5 year monthly to semi-monthly topographic surveys collected since 2005 at Truc Vert beach to address the time evolution of the alongshore-variable beach and dune response from the timescales of days (storm) to decades. Results show that 2 types of megacusp can be discriminated. (1) Accretive megacusps on the upper beach are enforced by the dynamics of inner-bar rip channels developing as a down-state morphological sequence. These megacusps with a spacing of $O(100 \mathrm{~m})$ have a typical lifetime of a few months, tend to migrate downdrift by $O(1 \mathrm{~m} /$ day $)$ and are smoothed out by severe, preferably obliquely-incident, storm waves. (2) Erosive megacusps are primarily enforced by the outer-bar morphology guiding intense rip currents during severe, shore-normally-incident, long-period storm waves. These erosive megacusps have therefore a larger spacing potentially exceeding $1 \mathrm{~km}$ in the southern part of the Gironde coast. Erosive megacusp embayments have the potential to cut the dune, causing localised dune erosion with the most documented event occurring during the outstanding winter 2013/2014. These erosive megacusps do not migrate and can persist during years to decades, particularly along the southern part of the coast that does not experience any significant chronic erosion. Results also show that the winter of 2013/2014, which was the most energetic since at least 1948, dramatically altered the coastal landscape and also impacted the behaviour and mean spacing of the accretive megacusps during the subsequent years. Overall, the study demonstrates the complex interplay between the nearshore morphology and the alongshore-variable changes of the foreshore/backshore from the timescales of days to decades, with occasional outstanding winters having the potential to deeply affect beach morphology and rhythmicity on the time scales of at least a few years.

\section{ACKNOWLEDGEMENTS}

The work was done in the framework of projects CHIPO (ANR-14-ASTR-0004-01) and SONO (ANR-17-CE01-0014) from the Agence Nationale de la Recherche (ANR). This study includes the monitoring study site of Truc Vert labelled by the Service National d'Observation (SNO) Dynalit (https://www.dynalit.fr) which also provides a framework for the long-term shoreline monitoring of the 110-km Gironde coast. The Observatoire de la Côte Aquitaine (OCA) provides additional financial support for the surveys. The wave buoy data used for model validation was provided by the French Candhis network operated by CEREMA. We thank MCIA for providing data storage facilities for this study.

\section{LITERATURE CITED}

Aagaard, T., 1988. Rhythmic beach and nearshore topography: examples from Denmark. Geografisk Tidsskrift, 88, 55-60.

Aagaard, T.; Greenwood, B., and Nielsen, J., 1997. Mean currents and sediment transport in a rip channel. Marine Geology, $140,25-45$

Almar, R.; Castelle, B.; Ruessink, B.G.; Sénéchal, N.; Bonneton, 
P., and Marieu, V., 2010. Two- and three-dimensional double-sandbar system behaviour under intense wave forcing and a meso-macro tidal range. Continental Shelf Research, 30, 781-792.

Ashton, A. and Murray, A.B., 2006. High-angle-wave instability and emergent shoreline shapes, Part 1: modeling of sand waves, flying spits, and capes. Journal of Geophysical Research, 111(F04011), doi: 10.1029/2005JF000422.

Ashton, A.; Murray, A.B., and Arnault, O., 2001. Formation of coastline features by large-scale instabilities induced by high-angle waves. Nature, 414, 296-300.

Aubie, S. and Tastet, J.-P., 2000. Coastal erosion, processes and rates: an historical study of the Gironde Coastline, Southwestern France. Journal of Coastal Research, 16, 756767.

Balouin, Y.; Tesson, J., and Gervais, M., 2013. Cuspate shoreline relationship with nearshore bar dynamics during storm events - field observations at Sète beach, France. In: Conley, D.C.; Masselink, G.; Russell, P.E., and O'Hare, T.J., (eds.), Proceedings 12th International Coastal Symposium (Plymouth, England), Journal of Coastal Research, Special Issue No. 65, pp. 440-445.

Barrère, P., 1992. Dynamics and management of the coastal dunes of the Landes, Gascony, France. In: Carter, R.W.G., et al. (Eds.), Coastal Dunes: Geomorphology, Ecology and Management for Conservation: Proceedings of the $3^{\text {rd }}$ European Dune Congress (Galway, Ireland), pp. 25-32.

Birrien, F.; Castelle, B.; Dailloux, D.; Marieu, V.; Rihouey, D., and Price, T.D., 2013. Video observation of megacusp evolution along a high-energy engineered sandy beach: Anglet, SW France. In: Conley, D.C.; Masselink, G.; Russell, P.E., and O'Hare, T.J., (eds.), Proceedings 12th International Coastal Symposium (Plymouth, England), Journal of Coastal Research, Special Issue No. 65, pp. 17271732.

Blossier, B.; Bryan, K.R.; Daly, C.J., and Winter, C., 2017. Spatial and temporal scales of shoreline morphodynamics derived from video camera observations for the islands of Sylt, German Wadden Sea. Geo-Marine Letters, 37, 11-123.

Bruneau, N.; Bonneton, P.; Castelle, B., and Pedreros, R., 2011. Modeling rip current circulations and vorticity in a highenergy meso-environment. Journal of Geophysical Research - Oceans, 116(C07026), doi: 10.1029/2010JC006343.

Bruneau, N.; Castelle, B.; Bonneton, P.; Pedreros, R.; Almar, R.; Bonneton, N.; Bretel, P.; Parisot, J.P., and Senechal, N., 2009. Field observations of an evolving rip current on a meso-macrotidal well-developed inner bar and rip morphology. Continental Shelf Research, 29, 1650-1662.

Castelle, B.; Bonneton, P.; Dupuis, H., and Sénéchal, N., 2007. Double bar beach dynamics on the high-energy mesomacrotidal French Aquitanian Coast: a review. Marine Geology, 245, 141-159.

Castelle, B.; Bujan, S.; Ferreira, S., and Dodet, G., 2017a. Foredune morphological changes and beach recovery from the extreme 2013/2014 winter at a high-energy sandy coast. Marine Geology, 385, 41-55.

Castelle, B.; Dodet, G.; Masselink, G., and Scott, T., 2017b. A new climate index controlling winter wave activity along the
Atlantic coast of Europe: The West Europe Pressure Anomaly. Geophysical Research Letters, 44 (3), 1384-1392.

Castelle, B.; Dodet, G.; Masselink, G., and Scott, T., $2018 \mathrm{~b}$. Increased winter-mean wave height, variability and periodicity in the North-East Atlantic over 1949-2017. Geophysical Research Letters, 45, doi:10.1002/2017GL076884.

Castelle, B.; Guillot, B.; Marieu, V.; Chaumillon, E.; Hanquiez, V.; Bujan, S., and Poppeschi, C., 2018a. Spatial and temporal patterns of shoreline change of a $280-\mathrm{km}$ highenergy disrupted sandy coast from 1950 to 2014: SW France. Estuarine, Coastal, and Shelf Science, 200, 212-223.

Castelle, B.; Marieu, V.; Bujan, S.; Ferreira, S.; Parisot, J.P.; Capo, S.; Senechal, N., and Chouzenoux, T., 2014. Equilibrium shoreline modelling of a high-energy mesomacrotidal multiple-barred beach. Marine Geology, 347, 8594.

Castelle, B.; Marieu, V.; Bujan, S.; Splinter, K.D.; Robinet, A.; Senechal, N., and Ferreira, S., 2015. Impact of the winter 2013-2014 series of severe western Europe storms on a double-barred sandy coast: beach and dune erosion and megacusp embayments. Geomorphology, 238, 135-148.

Castelle, B.; Ruessink, B.G.; Bonneton, P.; Marieu, V.; Bruneau, N., and Price, T.D., 2010a. Coupling mechanisms in double sandbar systems, Part 1: Patterns and physical explanation. Earth Surface Processes and Landforms, 35, 476-486.

Castelle, B.; Ruessink, B.G.; Bonneton, P.; Marieu, V.; Bruneau, N., and Price, T.D., 2010b. Coupling mechanisms in double sandbar systems, Part 2: Impact on alongshore variability of inner-bar rip channels. Earth Surface Processes and Landforms, 35, 771-781.

Castelle, B.; Scott, T.; Brander, R.W., and McCarroll, R.J., 2016. Rip current types, circulation and hazard. Earth-Science Reviews, 163, 1-21.

Coco, G.; Bryan, K.R.; Green, M.O.; Ruessink, B.G., and Turner, I.L., 2005. Video observations of shoreline and sandbar coupled dynamics. In: Proceedings of Coasts and Ports 2005, pp. 471-476.

Coco, G. and Murray, A.B., 2007. Patterns in the sand: from forcing templates to self-organization. Geomorphology, 91, 271-290.

Dalrymple, R.A.; MacMahan, J.H.; Reniers, A.J.H.M., and Nelko, V., 2011. Rip currents. Annual Review of Fluid Mechanics, 43, 551-581.

Davidson, M.A.; Splinter, K.D., and Turner, I.L., 2013. A simple equilibrium model for predicting shoreline change. Coastal Engineering, 73, 191-202.

Dodet, G.; Castelle, B.; Masselink, G.; Scott, T.; Davidson, M.; Floc'h, F.; Jackson, D., and Suanez, S., 2019. Beach recovery from extreme storm activity during the 2013/14 winter along the Atlantic coast of Europe. Earth Surface Processes and Landforms, 44(1), 393-401, doi:10.1002/esp.4500.

Dubarbier, B.; Castelle, B.; Ruessink, G., and Marieu, V., 2017. Mechanisms controlling the complete accretionary beach state sequence. Geophysical Research Letters, 44(11), 56455654.

Enjalbert, C.; Castelle, B.; Rihouey, D., and Dailloux, D., 2011. High-frequency video observation of a geologically- 
constrained barred-beach: La Grande Plage de Biarritz (France). In: Furmańczyk, K.; Giza, A., and Terefenko, P., (eds.), Proceedings of the 11th International Coastal Symposium (Szczecin, Poland), Journal of Coastal Research, Special Issue No. 64, pp. 70-74.

Falqués, A.; Coco, G., and Huntley, D., 2000. A mechanism for the generation of wave-driven rhythmic patterns in the surf zone. Journal of Geophysical Research, 105(C10), 2407124087, doi: 10.1029/2000JC900100.

Gallagher, E.L.; Elgar, S., and Thornton, E.B., 1998. Observations and predictions of megaripple migration in a natural surf zone. Nature, 394, 165-168.

Guza, R.T. and Inman, D.L., 1975. Edge waves and beach cusps. Journal of Geophysical Research, 80, 2997-3012.

Hemer, M.; Fan, Y.; Mori, N.; Semedo, A., and Wang, X., 2013. Projected changes in wave climate from a multi-model ensemble. Nature Climate Change, 3(5), 471-476, doi: 10.1038/nclimate1791.

Hesp, P., 1993. Edge Waves and Surfzone Dynamics: A Brief Review. Journal of Coastal Research, Special Issue No. 15, pp. 230-231.

Holland, K.T. and Holman, R.A., 1996. Field observations of beach cusps and swash motions. Marine Geology, 134, 7793.

Idier, D.; Castelle, B.; Charles, E., and Mallet, C., 2013. Longshore sediment flux hindcast: spatio-temporal variability along the SW Atlantic coast of France. In: Conley, D.C.; Masselink, G.; Russell, P.E., and O'Hare, T.J., (eds.), Proceedings 12th International Coastal Symposium (Plymouth, England), Journal of Coastal Research, Special Issue No. 65, pp. 1785-1790.

Kalnay, E.; Kanamitsu, M.; Kistler, R.; Collins, W.; Deaven, D.; Gandin, L.; Iredell, M.; Saha, S.; White, G.; Woollen, J.; Zhu, Y.; Chelliah, M.; Ebisuzaki, W.; Higgins, W.; Janowiak, J.; Mo, K.C.; Ropelewski, C.; Wang, J.; Leetmaa, A.; Reynolds, R.; Jenne, R., Joseph, D., 1996. The NCEP/NCAR 40-Year Reanalysis Project. Bulletin of the American Meteorological Society, 77, 437-472.

Lafon, V.; Dupuis, H.; Butel, R.; Castelle, B.; Michel, D.; Howa, H., and De Melo Apoluceno ,D., 2005. Morphodynamics of nearshore rhythmic sandbars in a mixed-energy envornment, 2: Physical forcing analysis. Estuarine, Coastal and Shelf Science, 65, 449-462.

Lafon, V.; Dupuis, H.; Howa, H., and Froidefond, J.M., 2002. Determining ridge and runnel longshore migration rate using SPOT imagery. Oceanologica Acta, 25, 149-158.

Laporte-Fauret, Q.; Marieu, V.; Castelle, B.; Michalet, R.; Bujan, S., and Rosebery, D., 2019. Low-cost UAV for highresolution and large-scale coastal dune change monitoring using photogrammetry. Journal of Marine Science and Engineering, 7(3), 63, doi:10.3390/jmse7030063.

LCHF (1979). Etude en nature de la Côte Aquitaine (entre la pointe de Grave et l'embouchure de l'Adour). Rapport pour la Mission Interministérielle pour pour l'Aménagement de la Côte Aquitaine, Laboratoire Central Hydraulique de France, 13-36p., in French.

MacMahan, J.H.; Thornton, E.B., and Reniers, A.J.H.M., 2006. Rip current review. Coastal Engineering, 53, 191-208.

Masselink, G.; Austin, M.; Scott, T.; Poate, T., and Russell, P.,
2014. Role of wave forcing, storms and NAO in outer bar dynamics on a high-energy, macro-tidal beach. Geomorphology, 226, 76-93.

Masselink, G.; Castelle, B.; Scott, T.; Dodet, G.; Suanez, S.; Jackson, D., and Floc'h, F., 2016. Extreme wave activity during 2013/2014 winter and morphological impacts along the Atlantic coast of Europe. Geophysical Research Letters, 43, 2135-2143, doi: 10.1002/2015GL067492.

Murray, A.B. and Thieler, E.R., 2004. A new hypothesis and exploratory model for the formation of large-scale innershelf sediment sorting and "rippled scour depressions". Continental Shelf Research, 24, 295-315.

Orzech, M.D.; Reniers, A.J.H.M.; Thornton, E.B., and MacMahan, J.H., 2011. Megacusps on rip channel bathymetry: Observations and modeling. Coastal Engineering, 58, 890-907.

Price, T.D.; Castelle, B.; Ranasinghe, R., and Ruessink, B.G., 2013. Coupled sandbar patterns and obliquely incident waves, Journal of Geophysical Research - Earth Surface, 118, 1-16, doi:10.1002/jgrf.20103.

Price, T.D. and Ruessink, B.G., 2013. Observations and conceptual modelling of morphological coupling in a double sandbar system. Earth Surface Processes and Landforms, 38, 477-489.

Price, T.D.; Ruessink, B.G., and Castelle, B., 2014. Morphological coupling in multiple sandbar systems - a review. Earth Surface Dynamics, 2, 309-321.

Ranasinghe, R.; Symonds, G.; Black, K., and Holman, R., 2004. Morphodynamics of intermediate beaches: A video imaging and numerical modelling study. Coastal Engineering, 51, 629-655.

Robinet, A.; Castelle, B.; Idier, D.; Le Cozannet, G.; Déqué, M., and Charles, E., 2016. Statistical modeling of interannual shoreline change driven by North Atlantic climate variability spanning 2000-2014 in the Bay of Biscay. Geo-Marine Letters, 36, 479-490.

Splinter, K.D.; Turner, I.L., and Davisdson, M.A., 2013. How much data is enough? The importance of morphological sampling and duration for calibration of empirical shoreline models. Coastal Engineering, 77, 14-27.

Splinter, K.D.; Turner, I.L.; Davidson, M.A.; Barnard, P.; Castelle, B., and Oltman-Shay, J., 2014. A generalized equilibrium model for predicting daily to interannual shoreline response. Journal of Geophysical Research, 119(9), 1936-1958, doi: 10.1002/2014JF003106.

Segura, L.E.; Hansen, J.E.; Lowe, R.J.; Symonds, G., and Contardo, S., 2018. Shoreline variability at a low-energy beach: contributions of storms, megacusps and sea-breeze cycles. Marine Geology, 400, 94-106.

Shepard, F.P.; Emery, K.O., and Lafond, E.C., 1941. Rip currents: a process of geological importance. Journal of Geology, 49, 338-369.

Sonu, C.J., 1973. Three-dimensional beach changes. Journal of Geology, 81, 42-64.

Tastet, J.-P. and Pontee, N.P., 1998. Morpho-chronology of coastal dunes in Médoc: a new interpretation of Holocene dunes in Southwestern France. Geomorphology, 25, 93-109.

Thornton, E.B.; MacMahan, J.H., and Sallenger Jr., A.H., 2007. Rip currents, mega-cusps, and eroding dunes. Marine 
Geology, 240, 151-167.

Tolman, H.L., 2014. User manual and system documentation of WAVEWATCH III, Version 4.18 . NOAA/NWS/NCEP/MMAB Technical Note, 316 p.

van Enckevort, I.M.J.; Ruessink, B.G.; Coco, G.; Suzuki, K.; Turner, I.L., Plant, N.G., and Holman, R.A., 2004. Observations of nearshore crescentic sandbars. Journal of Geophysical Research, 109(C06028), doi: 10.1029/2003JC002214.

van de Lageweg, W.I.; Bryan, K.R.; Coco, G., and Ruessink, B.G., 2013. Observations of shoreline sandbar coupling on an embayed beach. Marine Geology, 344, 101-114.
Wang, X. L.; Feng, Y., and Swail, V.R., 2014. Changes in global ocean wave heights as projected using multimodel CMIP5 simulations. Geophysical Research Letters, 41(3), 10261034, doi: 10.1002/2013GL058650.

Wright, L.D. and Short, A.D., 1984. Morphodynamic variability of surf zones and beaches: A synthesis. Marine Geology, 56, 93-118.

Yates, M.L.; Guza, R.T., and O'Reilly, W.C., 2009. Equilibrium shoreline response: observations and modeling. Journal of Geophysical Research, 114(C09014), doi: 10.1029/2009JC005359. 